\title{
In Lieu of a Conclusion: The Totalitarian Challenge
}

Among the proponents of a modern Confucianism who addressed the topic of totalitarianism, Tang Junyi's political thought stands out. Indeed, from the early 1950s onwards, Tang's reflections on totalitarianism were more comprehensive than those of the vast majority of his fellow Confucian thinkers. ${ }^{1}$ A discussion of Tang's writings on totalitarianism needs to take his own claim regarding the global significance of modern Confucianism at face value. ${ }^{2}$ Tang of course did not address totalitarianism by focusing exclusively on Chinese communism, but made reference to what he identified as Western European and Russian phenomena of totalitarian rule. What is conspicuously absent, however, is a reflection on a defining experience of the modern West that was brought about by a totalitarian regime: the Holocaust. I do not point this out as a way of counterbalancing the fact that Western philosophers have often paid only scant attention to the non-Western world in their reflections on modernity. Rather, I want to suggest that if we are to take the Confucian claims to global significance seriously, we need to consider the problem that the Confucian critiques of "Western modernity" have largely ignored the Holocaust and hence revolve around a black hole. A rigid exegete of Tang's work might content himor herself with stating that Tang, for whatever reason, chose to forgo a discussion of the Holocaust. There are other options, however. For one, we can relate Tang's thought to a reflection on the Holocaust and examine to what effect it might contribute to our understanding of this cataclysmic experience. In this

1 For example, Zhang Junmai commented on international communism and Chinese communism after the Second World War (see Zhang's articles in Zhang Junmai yanlun ji. Yijiusijiu nian yihou, Vols. 2, 3, 4). In the 193 os he had written a book about the Soviet Union under Stalin, covering the period from 1928 to 1933 (The Soviet Union Under Stalin; 1933), and published a brief comparison of the dictatorships in the Soviet Union, Nazi Germany and Fascist Italy (in his The Way to Establish the State; 1938), using terms such as "fascist" or "autocracy;" see Zhang, Shitailin xia zhi Su'e; Zhang, Li guo zhi dao, pp. 117-137.

2 Such claims have been repeated time and again since the end of the Second World War, for example in the Confucian manifesto of $195^{8}$ (Zhang, Zhongguo wenhua yu shijie). More recently, Tu Wei-ming prominently raises similar claims about the global significance of a renewed Confucian humanism; see e.g. Tu, "Multiple Modernities-Implications of the Rise of 'Confucian' East Asia," pp. 6o, 66-67. 
sense, the present chapter, much like the previous ones, is an attempt to think with Tang, instead of merely thinking about him.

At first glance, Tang Junyi seemed to be in an awkward position to examine the formation and various manifestations of totalitarianism, because he hardly took account of speculative elements that are often considered fundamental to totalitarian ideologies. Among these are secularized eschatologies stemming from philosophies of history, complete with ideas about a historical struggle of humanity against its enemies, and the accompanying belief in the final, thisworldly elimination of all antinomies. It is thus not surprising that in his analysis of totalitarianism he did not attempt to explore the ideological foundations of Western forms of totalitarianism in a comprehensive manner. Yet he apparently felt that to remain silent on totalitarianism was not an option. Given the experience of European fascism, National Socialism, Stalinism, the communist takeover of the Chinese Mainland and the tensions of the Cold War period, the need to examine totalitarianism was compelling, even more so because Tang was convinced by the early 195 os that the government of the PRC was in fact a totalitarian regime (see below).

Apart from the harsh experience of civil wars and world wars leading up to the mid-2oth century, other issues engendered Tang's interest in totalitarianism. Most of all, his optimistic outlook on human history in general and on the global course of modernity in particular was at stake. If an analysis of totalitarianism would show that totalitarian societies were as likely to be the outcome of modernization as democratic societies, then this optimism would have been shattered. What is more, the renewal of "humanism" that was at the core of modern Confucianism had to measure up to the catastrophic experience of totalitarianism if it was to avoid the criticism of being a mere reverie of an idyllic world or, worse still, a naïve escapism that curtails critical thought. The following shows that, Tang addressed these challenges in his reflections on totalitarianism, but he did so in a highly selective manner when it came to include the history of non-Chinese totalitarianism. Far from leaping into such reverie, Tang assumed that totalitarianism was neither non-modern nor anti-modern, nor a mere aberration that occurred as a singular event in the course of Western-induced modernity.

\section{On the Origins and Causes of Totalitarianism}

Tang probably first dealt with the problem of totalitarianism in 1951, when he wrote an article for the Democratic Review about repressive and violent 
measures taken by the communist regime on the Mainland. ${ }^{3}$ His choice to publish this text in the Democratic Review set a precedent for the following decades, when he continued to publish articles on totalitarianism in journals that appealed to a broad readership. Whereas the historical contexts of Tang's interest in analyzing totalitarian rule can be readily discerned, we can only speculate about the theoretical inputs he had absorbed. It is not unlikely that he was aware, in the early 1950s, of American discussions about totalitarianism that had begun in the mid-1930s. On the whole, Tang's analyses are to some degree in line with conservative critics from the American Review of Politics: these critics had assumed that a totalitarian reaction was triggered by a fatal crisis of Western civilization, complete with an equally disastrous crisis of capitalism, which entailed unrestrained materialism, rampant individualism and a widespread spiritual void in modern Western societies. Consequently, some of these conservative thinkers identified an ethical renewal of society as the essential antidote to totalitarianism. ${ }^{4}$

Tang neither devised a theory of totalitarianism nor presented a comprehensive analysis of totalitarian ideologies or totalitarian regimes. This is, however, not surprising given the state of international studies on totalitarianism on which one commentator recently concluded: “'Totalitarianism' remains as ambiguous today as ever: as a historical concept it is insecure and contested, as memory it is geographically promiscuous and unstable, and nebulous; only as a semantic marker of new political constellations, identities, and ideological alli-

3 The article is entitled "Is a Human Being a Human Being after All?" and was published in Minzhu Pinglun, Vol. 2, No. 24 (June 1951); see Tang, Zhonghua renwen yu dangjin shijie bubian, Vol. 10, pp. 131-137.

4 On the early American debate about totalitarianism, see Knöbl, Spielräume der Modernisierung, pp.116-120. The Review of Politics was founded in a Catholic milieu. John Nef, an economic historian from Chicago University, warned about the detrimental effects of unrestrained materialism and the crisis of capitalism in Western societies including the United States in 1940: Knöbl, ibid., p. 119. American public and academic debates about totalitarianism date back to the 1930s and over time comprised a broad intellectual and political spectrum, at one time bringing together socialists, liberals and conservatives in the "Committee for Cultural Freedom" founded by philosophers Sidney Hook and John Dewey in 1939. The scope of "totalitarianism" was contested throughout and discussions responded to shifts in international politics, from the Hitler-Stalin Pact to the U.s. cooperation with the Soviet Union in the war against Nazi Germany and to the subsequent rift in the Cold War period, which led to a revival of studies on totalitarianism in the 1950s; see Rabinbach, "Moments of Totalitarianism," pp. 89-93; Gregor, Marxism, Fascism, and Totalitarianism: Chapters in the Intellectual History of Radicalism, pp. 12-14. 
ances is it, as ever, indisputable." ${ }^{5}$ As for Tang's writings on totalitarianism, we find no comparative analysis of the inner workings of totalitarian regimes of the 2oth century, even though he conceptualized totalitarianism to include Italian Fascism, National Socialism, Stalinism, and Chinese communism. Nor did he analyze ideological components of totalitarianism such as fascism, racist ideologies or anti-Semitism. Overall, he applied the label of totalitarianism in a very loose, sometimes polemical manner.

With regards to the system of Chinese communism, Tang did not examine it in a comprehensive manner, but rather presented detailed observations about its workings and inscribed these into a larger theoretical framework of totalitarianism[s]. From the 1950s to the 1970s he used the terms "totalitarianism” (jiquanzhuyi 極權主義), “totalitarian world” (jiquan shijie 極權世界), “totalitarian system” (jiquan zhidu 極權制度), “totalitarian society” (jiquan de shehui 極權的社會) and “totalitarian politics" (jiquan de zhengzhi 極權的政治) to refer to Chinese "totalitarianism from Qin Shihuang up to the contemporary Qin Shihuang-ism of Mao Zedong,"6 to the European "Fascists" Mussolini and Hitler and to the Russian "communists" Lenin and Stalin. ${ }^{7}$ Whether Tang's use of "totalitarianism" includes GMD rule, which he believed was "fascist" during the period from the dissolution of the first united front in the mid-192os until the end of the Second World War, is not entirely clear. ${ }^{8}$ Be that as it may, Tang gives the concept of totalitarianism a very broad extension here, which comprises even the dynastic rule of the Qin as well as czarist Russia. ${ }^{9}$

It is deplorable that Tang did not substantiate this extensive use of "totalitarianism." Whether he actually believed that there were intellectual or institutional roots of totalitarianism reaching back to the Qin Dynasty and whether he, therefore, agreed with Xu Fuguan's diagnosis of Chinese despotism, remains

5 Rabinbach, "Moments of Totalitarianism," p. 100. In the same vein, A. James Gregor states in a recent study that "[w] hat 'totalitarianism' is not is a 'theory'. (...) It is not clear that all members of the class share all its defining traits — nor is it clear how many of those defining traits, or in what measure, are required for entry into the class." Gregor, Marxism, Fascism, and Totalitarianism: Chapters in the Intellectual History of Radicalism. p. 17.

6 See a 1974 article by Tang in Mingbao: Tang, Zhonghua renwen yu dangjin shijie, Vol. 8, p. 428. The reference to Mao Zedong pertains to Chinese communism of the early 1950s; see Tang, Zhonghua renwen yu dangjin shijie bubian, Vol. 10, p. 136.

7 Tang, Zhonghua renwen yu dangjin shijie, Vol. 8, p. 331.

8 For Tang's diagnosis of fascist tendencies in the GMD; see Tang, Zhonghua renwen yu dangjin shijie bubian, Vol. 10, pp. 157-158.

9 Tang, Zhonghua renwen yu dangjin shijie, Vol. 8, pp. 318-319. 
doubtful. ${ }^{10}$ What is more, Xu Fuguan polemicized in the early 1950 s against Tang and Mou Zongsan by claiming that their project of modern Confucianism was not immune to an absorption by totalitarian ideas. ${ }^{11}$ In countering Xu's criticism, Tang presented a conceptual argument as well as a historical interpretation. On the conceptual level, as we have seen, he proposed a definition of politics that placed the emphasis on the need to confine politics to an institutional realm without imposing it on other spheres within society. Politics had to be functionally limited to the task of indirectly supporting the realization of social and cultural values by safeguarding the organizational and institutional framework. Aside from these systematic considerations, Tang reacted to $\mathrm{Xu}$ Fuguan's criticism with an attempt to discern intellectual currents in Chinese history that are characterized, to some degree, by an affinity to totalitarianism. This approach is typical of Tang's profound skepticism towards the political traditions of Confucianism, which in fact exceeds Xu Fuguan's critique of the Confucian tradition. As Tang saw it, the Confucians of the past had tried to endow their doctrines with immediate ruling power by propagating the idea that the "ruler" (jun 君) and the (highest) "teacher" (shi 師) should be one and the same person. ${ }^{12}$

Tang detected similar tendencies of infusing politics with totalizing, doctrinal claims to truth in strands of Buddhism, Daoism and "original" Christianity, ${ }^{13}$ but he primarily targeted the New Culture Movement of the 2oth century, insinuating strong affinities to totalitarian thought. These affinities are said to become manifest in the conviction of New Culture advocators that the totality of extant drawbacks in Chinese society can be removed by implementing a new, anti-traditional and anti-metaphysical culture in a surgical manner. Accordingly, the totalizing notion of a "new culture" promised to eliminate all the remnants of Confucianism, including the familial virtue of filial piety, and to replace the social significance of religions altogether with "science and democracy." In his criticism of such a belief in the salutary conflation of politics

10 As Liu Honghe points out, Xu Fuguan assumed in his study of centralized, bureaucratic rule in imperial China that a "totalitarian" type of despotism evolved in the Qin and Han Dynasties and persisted, in various forms, throughout imperial China; see. Liu, Confucianism in the Eyes of a Confucian Liberal. Hsu Fu-kuan's Critical Examination of the Confucian Political Tradition, pp. 111-112.

11 Tang, Zhonghua renwen yu dangjin shijie bubian, Vol. 10, pp. 226-227.

12 Ibid., p. 235 .

13 Ibid. According to Tang, in these currents the evil in politics was considered to be identical with the evil in man. The ensuing attempts to eradicate all evil intentions in man were in effect attempts to transcend politics and its evils once and for all. As a consequence for practical life, politics would thus be depleted of its contents. 
and true doctrines, Tang arrived at the drastic conclusion that the New Culture Movement on the whole played a crucial role in facilitating the spread of communism in China. ${ }^{14}$

Given Tang's very broad conceptual extension of "totalitarianism," it is not surprising that he did not present a clear-cut definition of totalitarianism, but instead contented himself with elucidating certain characteristics and mechanisms of totalitarian rule and ideologies. Tellingly, the focus is here on communist rule in China, and not on Soviet Stalinism or National Socialism. In 1951, on the occasion of writing about trials and killings in communist China that involved incidents of children exposing crimes allegedly committed by their parents, Tang deemed these incidents to be "unbearable." He added that Chinese communists' "massacres" and repressive propaganda could not be fully comprehended by solely analyzing some specific political or other reasons for such actions..$^{15}$ The communist concept of politics according to which "politics" was to rule and control every aspect of human life, and which allowed only for a single distinction - the one between a "we"-group and an enemy who must be eliminated-had to be taken into account. The involvement of children's accusations in the execution of their parents was, it seemed, to serve the purpose of eliminating the very root of "humaneness" in human beings, namely by eradicating the sphere of intimate feeling for one's parents as the initial expression of humaneness. ${ }^{16}$ The totalitarian politics of Chinese communism aimed, therefore, not only at dehumanizing the enemy; it also served to create a "we"-group whose members are similarly incriminated and entangled in dehumanizing acts of breaking taboos that amount to a fundamental denial of humaneness. Tang hence called Chinese communism an ideology of "negating everything" ( fouding yiqie 否定一切), which thereby attained the intensity of a "new religion." By reifying the human being to the point of dehumanization, the ideology of Chinese communism was truly "satanic."17

There are two conclusions that we might draw here: First, the communist campaign to systematically dissolve familial ties was an attempt to destroy those social and ethical relations that play an important role in the formation of an individual's personal identity. Second, there are mechanisms of totalitarian rule that function to categorize the victims under anonymous, de-individualized labels, thereby facilitating a decrease of solidarity and a

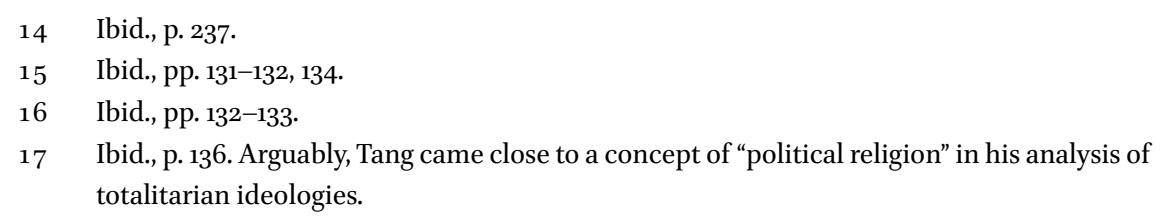


growing indifference on the part of bystanders. With respect to incriminating the "we"-group into the acts of the perpetrators, the term "satanic" is relevant because it links Tang's analysis to his reflection on the human lust for power and inclination toward cruelty (see Chap. 7 "The Political and its Demonic Aspects"). It is implied here that the totalitarian mechanisms of Chinese communism radically dissolve ethical relations and social contexts of humanistic culture, and hence serve to expose the individuals to their own self-consuming lust for power. ${ }^{18}$ Incriminated, exposed and de-individualized human beings would now be ready to participate in the violent tearing down of the old order. Tang alluded to this aspect of totalitarian ideology in his sharp rejection of revolutionary morality:

The communists' acclamation of revolutionary morality as the highest morality of man is one type of pan-moralism which is morality perverted for a political purpose. The ideology of such a pan-moralism can strip a man of all his cultural garments and sacrifice him naked on the altar of political revolution. Such an attitude, be it admitted, is not without moral sentiment originating from within. But, nonetheless, when the naked moral being of a revolutionary hero is worshipped above all men, the preservation of traditional human culture would be considered as of no essential importance, and barbarism among other things will come out from this very pan-moralism. ${ }^{19}$

However, totalitarian rule in communist China was ridden with inner contradictions, even regarding the treatment of familial ties. Tang recognized that the communist regime did not intend to dissolve these ties altogether, but rather tried to make use of them in order to secure and exert power within the ruling circles. Two particularly striking cases were the ascendance to power of Mao's wife, Jiang Qing, and the Red Guards' intimate attachment to Mao that culminated in their fervent admiration of the "Great Helmsman." This

18 Tang explicitly stated that in the world of Marxism-Leninism, human beings are deprived of opportunities to rely on a moral or cultural way of life in order to rein in their lust for power. He added that for the Communist Party, the existence of political power is identical with the existence of human life; see an unpublished manuscript from 1972 entitled "On the Contradiction between Chinese Nationalism and Marxism-Leninism, and on the Road of China," reprinted in Tang, Zhonghua renwen yu dangjin shijie bubian, Vol. 10, p. 422. See also Tang's diagnosis of the totalitarian politicization, and hence destruction, of the humanistic realm in the PrC: Tang, Renwen jingshen zhi chongian, pp. 65, 388. 
was, according to Tang, clearly reminiscent of familial ties and was probably even inspired by Mao's earlier readings of late imperial novels such as The Romance of the Three Kingdoms and Water Margin. ${ }^{20}$ The obvious conclusion is that communist rule in China had to rely on such traditional measures to secure power because it was permanently faced with severe ideological contradictions. Among these, the ideological tensions between universal aspirations to world revolution and particular claims of Chinese nationalism that took shape in the rift between a pro-Soviet and an anti-Soviet camp within the CCP stand out. It is regrettable that Tang did not attempt to inscribe such detailed observations of the inner workings and mechanisms of totalitarian rule on the Chinese Mainland into a systematic examination of Chinese totalitarianism. Instead, he tried to detect particular signs of contradictions within communism in China, never attempting to systematize his observations in the manner of Franz Neumann's Behemoth (1942/1944), which contains an analysis of the inner antagonisms, rampant contradictions and chaotic aspects of National Socialism. Neither did Tang try to relate his observations about the Chinese communist state to an extensive examination of totalitarianism on the scale of Friedrich and Brzezinski's classical Totalitarian Dictatorship and Autocracy (1956), which he most likely had not studied.

Even though Tang did not present a comprehensive analysis of totalitarianism, he did try to uncover the sources of totalitarianism. His approachloosely similar to Hannah Arendt's in The Origins of Totalitarianism from 1951-highlights factors that were conducive to the emergence of totalitarian rule without claiming to identify all the compelling causes that lead to totalitarianism. Such an approach involves vastly different elements and layers. With respect to the question of why individuals show inclinations towards totalitarianism, Tang turned to habitual attitudes. He identified a specific "attitude of thinking" that is best described as a "passive state" in which individuals "habitually conform to opinions that they themselves have naturally formed." Due to a lack of intellectual alertness and reflection, individuals are particularly prone to fall victim to political, religious and social propaganda that aims to make them readily conform to a "totalitarian system." In a pessimistic diagnosis, Tang ascertained that these attitudes are very difficult to alter. ${ }^{21}$ One effect of such habitual passiveness can even be seen, he believed, in the United States where many people strove solely for their own personal gain while trying to minimize their losses vis-à-vis their government. Similarly, many overseas

\footnotetext{
20 Tang, Zhonghua renwen yu dangjin shijie bubian, Vol. 10, pp. 427-429 (unpublished manuscript).

21 Tang, Renwen jingshen zhi chongjian, pp. 572-573.
} 
emigrants from China became increasingly unwilling to actively resist totalitarianism the longer they lived in the "free world" (ziyou shijie 自由世界). ${ }^{22}$

On a different level of analysis, Tang diagnosed the decline of the individual in modernity and related this development to the rise of totalitarianism. He depicted modern societies as characterized by the excessive spread of instrumental rationality throughout the political, social, cultural and economic sphere. As a consequence, the individuals understand, evaluate and organize their own lifeworld, including their mutual relations and their selfconceptions, solely in consideration of efficiency and utility, thereby reifying the human being itself. The objectified human being is thus put at the disposition of the alleged overall progress of society. The quintessence of Tang's diagnosis of modernity is evident from his conclusion that there is a potential convergence between totalitarian and liberal societies in the common degeneration of the individual: Both totalitarian societies and societies of "laissezfaire individualism" are made up of individuals who are closely enmeshed in an unrestrained quest for wealth, power, and prestige which eventually leads to the individual's loss of a "feeling of authentic existence" (zhenshi cunzai gan 真實存在感). ${ }^{23}$ The decline of the "authentic self" pertains to the individual's loss of self-awareness as a being that is capable of lifting itself up to the realm of sagehood-and to achieve this not at the cost of others but on the basis of recognizing each other's political and social freedom as a precondition for one's quest for self-cultivation. This decline in turn gives rise to the formation of an isolated and alienated self in the spheres of politics, society, and "academic culture." This self is utilizing human beings as means to maximize its gains in terms of wealth, power and prestige, thereby exterminating those forms of recognition that do not accord with instrumental rationality. Such objectification affects not only the others but also encapsulates the self. It eventually turns into an atomistic self that is particularly prone, according to Tang, to the lures of totalitarianism. ${ }^{24}$

22 See Tang's 1958 article in Zuguo Zhoukan, Vol. 28, No. 3-5; reprinted in Tang, Zhonghua renwen yu dangjin shijie, Vol. 8, here: p. 110.

23 Ibid., pp. 424-425. Tang stated, in the manner of Western mainstream criticisms of reifying effects of modernity: “... modern man, who sees and does nothing other than what his profession demands of him, leads a way of life more or less like a bee or an ant, thus degrading the human spirit"; see Tang, "The Reconstruction of Confucianism and the Modernization of Asia," p. 370.

24 Tang, Zhonghua renwen yu dangjin shijie, Vol. 8, p. 424-427, 428. Tang was here referring, among others, to Jaspers, Buber, and Sartre as philosophers who warned that the basic problem of human existence in the 2oth century, in capitalist as well as socialist societies, was not so much one of material life as one of a deepening isolation and solitude on 
In this context, Tang turned to the global ascension of a Janus-faced scientific civilization that is crucial to "free and democratic societies" but may also function as a trajectory for the reification of modern man:

If man is regarded merely as an object in the external world, then like other external objects he has no reason not to be used, controlled and manufactured. The totalitarian states do in fact use scientific knowledge and techniques to remold men for political purposes, degrading their dignity and condemning their soul. Here we can again see the need for Confucian teachings, which respect scientific study on the one hand, and hold sacred the transcendental subjectivity of man on the other. ${ }^{25}$

Without critical reflection on the mixed blessing of the modern advancement of science and technology, a failure of the project of modernity is looming. The reconstruction of Confucianism was thus to serve as a bulwark against such danger. This entailed repeated warnings against the totalizing reification of the human being in modern societies, including totalitarian societies which also make comprehensive use of modern science and technology. Here Tang drew a parallel between the repressive regimes of Nazi Germany and Stalinist Soviet Union:

For example, Hitler and Stalin and other dictators all made use of scientific and technological methods to build a human society. But what kind of society did they actually build? They applied scientific and technological methods to control and enchain the freedom of humanity, form autocratic and dictatorial politics, and destroy democratic institutions. [This] was evidently even more effective than not using scientific and technological methods. ${ }^{26}$

Another layer of origins of Chinese totalitarianism pertains to the peculiar historical conditions under which communism took hold in China. In Tang's view, "Marxism-Leninism" became accepted in China in the context of widespread anxieties among the Chinese about the survival of their nation amid imperialistic threats foreign nation-states posed since the mid-19th century.

the part of the individual, which runs counter to an "authentic" mode of life; see Tang, Zhonghua renwen yu dangjin shijie bubian, Vol. 10, p. 435 (unpublished manuscript). 
Communism was thus seen as a powerful weapon to resist imperialistic intrusions and also as a tool to strengthen the Chinese nation. ${ }^{27}$ This perception certainly fit the popular view that the whole Chinese nation had become a "proletarian class" at the hands of "capitalist states of the West." Besides, the fact that Marxism-Leninism was "anti-Western Western thought" decisively enhanced, it seems, its attractiveness in the Chinese world. ${ }^{28}$ Whether Tang himself agreed with this view is open to discussion. He did not, after all, clarify the meaning of capitalism nor its relation to imperialism and colonialism. His analysis of Western imperialism suggested, however, that socioeconomic groups and organizations within Western nation-states were the driving agents propelling imperialistic politics (see Chap. 7 "The World Order of 'Ecumenical States"). Hence the submission of the nation-state to forces from the socioeconomic sphere was a crucial prerequisite for imperialistic action, which in turn effectuated a totalitarian backlash in the victimized countries. Tang consequently insisted on the need to establish strong nation-states in order to contain totalitarianism. Only within the institutional setting of democratic nation-states would the societal sphere with its capitalist dynamic be reined in, and a totalitarian backlash therefore prevented. The nation-state in its political form of liberal democracy was thus identified as a bulwark against totalitarianism, and its absence in China had particularly disastrous consequences.

Perhaps it is due to this diagnosis that Tang never considered the quest for a strong nation-state as a potential origin of Chinese totalitarianism. He instead bolstered his analysis by drawing his readers' attention to the fact that Mussolini, Hitler, Lenin and Stalin all proclaimed their determination to resist "inequality and crimes in the capitalist societies of the modern West" when they successfully mobilized the masses. ${ }^{29}$ This analysis is highly problematic, not only because the generalizing equation of Italian Fascism, National Socialism, Leninism and Stalinism is misleading from a historical point of view. Equally disturbing is the implicit vindication of totalitarianism as a form of self-defensive reaction against severe capitalist or imperialistic threats to one's nation.

27 Tang, Zhonghua renwen yu dangjin shijie bubian, Vol. 10, p. 445 (unpublished manuscript).

28 See an interview with Tang from 1974 in Mingbao, reprinted in: Tang, Zhonghua renwen yu dangjin shijie, Vol. 8, pp. 318-319.

29 See an interview with Tang from 1974 in Mingbao (Hong Kong), reprinted in Tang, ibid., p. 331 . 


\section{Overcoming Totalitarianism?}

The strengthening of (democratic) nation-states vis-à-vis transnational socioeconomic aspirations of imperialistic expansion is not the only means of curbing the danger of totalitarianism that Tang discussed. He also deemed it imperative, as we have seen, to initiate a renewal of humanistic thought and values (e.g. as a renewal of a "classical spirit") within a liberal democracy. He related this agenda explicitly to the struggle of the "free world" against the "totalitarian world," which he saw unfolding in the 1950s as a struggle that should involve the reconstruction of a "democratic spirit."30 The notion "democratic spirit" refers to the conviction that the stability of democratic government requires the social diffusion of a humanistic culture. Tang thus warned, in an interview from 1974, that because democracy was abused by totalitarianism in the 2oth century, establishing a kind of "education and culture" that generates common knowledge about "true democratic political institutions" was now necessary. ${ }^{31}$ When seen from this perspective, the modern Confucian project to interweave the renewal of China's humanistic "main current" with the adoption of a democratic political form is also an attempt to fend off totalitarianism.

Tang's modern Confucianism entails, if not a detailed prediction about the future of Chinese totalitarianism, then at least the general prediction that totalitarianism is bound to eventually collapse in China primarily because of its antagonistic stance toward the "main current" of China's "national culture." In the manifesto of 1958, Tang and his co-authors expected that Chinese Marxism-Leninism would falter due to the self-destructive power struggles within its ruling elite, but most of all because of its erroneous concepts of human nature and culture that are fixed to the "standpoint of class." These concepts were said to run counter to globally shared principles of "higher culture" and also to China's "cultural thought" of several millennia, which refers to the "[human] mind" and "human nature" in order to establish the "moral subject." ${ }^{2}$ Tang, who frequently repeated this expectation from the 1950 s to the 1970s, here once again deployed-implicitly - the tautological depiction of the relation between the Chinese nation and its "main current" (see Chap. 4

$30 \quad$ Ibid., p. 104.

31 Ibid., p. 331. He had already claimed in 1951 that the problem of "Chinese communism" was in fact neither a problem that was primarily related to certain political parties nor to certain political systems, but rather a problem of "culture" and "mind and [human] nature”; see Tang, Zhonghua renwen yu dangjin shijie bubian, Vol. 10, p. 136. 
"Nation and Culture"). The tautology of the prognosis asserts, in essence, that totalitarianism is not entrenched in the cultural "main current" of the Chinese nation, whereas the democratic nation-state is indeed its authentic political form. Accordingly, there is no historical "necessity" for the victory of totalitarianism (i.e. "Marxism-Leninism") in China. Establishing a democratic nationstate, on the other hand, will eventually occur as "evidenced" by the fact that it is in accordance with the "main current" that shapes the course of Chinese history. ${ }^{33}$

However, as we have seen, Tang did not conceptualize this historical development as a result of linear, planned human action. The individuals are unburdened, in Tang's theory of state, from the need to unreservedly identify themselves with factual efforts of nation-state building. Similar to the socalled Hegelian Left, Tang's political hermeneutics distinguish clearly between the truth claims of the state in historical reality and the truth of the concept or the idea of the state: the "idea of the state" (guojia zhi linian 國家之理念) is a "purely spiritual idea" (chuncui jingshen de linian 純粹精神的理念). ${ }^{34}$ The historical reality of the state, in other words, is not to be considered an immediate manifestation of reason. ${ }^{35}$ In a somber mood, Tang drew the distinction, in 1955, between the "Republic of China" as the label for a pending effort of state building on the one hand, and as the denominator for the contemporary, unsatisfying reality represented by the current state of the Chinese Republic on the other:

Although today's national government has retreated to Taiwan, the question about its achievements in carrying out democratic, constitutional politics is another matter altogether. But nothing will ultimately be able

33 Tang, Zhonghua renwen yu dangjin shijie, Vol. 8, pp. 318-319; see also Tang, Zhonghua renwen yu dangjin shijie bubian, Vol. 10, pp. 445-446 (unpublished manuscript); Zhang, Zhongguo wenhua yu shijie, pp. 44-45. In the same vein, Tang made retrospective prognostications in the form of historical diagnoses. Among these, we find his highly questionable dictum that contemporary Russia, due to its "totalitarian" tradition of czarism, was far more likely to witness a prolonged totalitarian era than China, whose "totalitarian" past had merely lasted for the very short period of the Qin Dynasty; see Tang, Zhonghua renwen yu dangjin shijie, Vol. 8, pp. 318-319.

Tang, Renwen jingshen zhi chongjian, pp. 392-393.

35 The so-called Hegelian Right in Germany is often said to have considered the factual state as the rational state, whereas the Hegelian Left attempted to conceptualize a future human community in which alienation and the institutions of the state would have ceased to exist; see Vollrath, Grundlegung einer philosophischen Theorie des Politischen, p. 128. 
to obstruct the Chinese nation from proceeding along this path, in order for the Republic of China to make a name for itself and conform, in actuality, to [the concept of the] Republic of China. [...] The outer impediments consist, of course, in the Communist Party, which completely disagrees with the spirit of the Chinese Republic striving for the construction of a 'Chinese, national, democratic state', and [instead] solely believes in Marxism-Leninism, one-sidedly [establishing] an autocracy of one party and one class. ${ }^{36}$

Furthermore, Tang did not assume that the concept of the state wields such power over reality as to enforce its own implementation by prefiguring and anticipating actual political and social movements. ${ }^{37}$ In accordance with this conceptual delimitation of the theory of the state, Tang repudiated Kang Youwei's vision of a limitless world of "great uniformity" in which all extant legal, political, social and cultural "boundaries" ( jie 界) and institutions would eventually dissolve:

If we again imagine that in an ideal world everybody would generally have only one [way of] thinking, one [single] will, one [way of] feeling, and would lead the same cultural life, again without any difference, then the interchange of human thought would no longer exist, and neither would affectionate mutual concern ... This would amount solely to the death of the humanistic world... Our ideal world is thus not a world of identity in which there is no difference between human beings... We therefore do not call our ideal world a world of great uniformity, but rather a world of grand harmony (tai he 太和). The difference between harmony (he 和) and uniformity (tong 同) is something that we must urgently recognize. ${ }^{38}$

We may conclude from this critique that such visions of a great uniformity are totalitarian in essence, not only because they applaud a totalitarian

36 Tang, Zhongguo renwen jingshen zhi fazhan, pp. 175-176 (this article was first published in Zuguo Zhoukan, Vol. 12, No. 7; November 1955).

37 Koselleck called this latter type of concepts, which gained wide currency after the French Revolution, "collective and motivating concepts capable of reordering and mobilizing anew the masses." These concepts, many of which were "isms," aided political mobilization and were (and still are) used not only in academic contexts, but also as political watchwords; see Koselleck, Futures Past: On the Semantics of Historical Time, p. 80.

38 Tang, Renwen jingshen zhi chongjian, pp. 71-72 (this article was published in Minzhu Pinglun, Vol. 1, No. 2; July 1949). 
future, but also because the visionaries ascribe to their own ideas a totalizing, reality-consuming power. The danger, then, lies in the assumption that the respective "ideals" wield total power over reality. Tang tried to hold this totalitarian implication at bay when he pinned down "ideals" by introducing notions of sagehood and moral intuition as limit-concepts.

Given this astute awareness of ideological aberration of totalitarianism, it may seem perplexing that Tang, for all his criticism of the downsides of Western types of modernity and modernization, refrained from linking the critique of modernity/modernization more closely with a diagnosis of Western types of totalitarianism. As for the mainstream of contemporary Confucian thought, an even more perplexing image emerges. It is indeed ironic that Confucian critics of "Western modernity" generally stop short of tapping into those intense Western debates about modernity that take up the issue of the project of Western Enlightenment reverting into a totalitarian collapse of civilization. By abstaining from these debates, the Confucian reflection on modernity evades disturbing questions and unsettling perspectives, above all the acknowledgment of "the gnawing suspicion" that Zygmunt Bauman expressed, namely "that the Holocaust could be more than an aberration ... from the otherwise straight path of progress... We suspect (even if we refuse to admit it) that the Holocaust could merely have uncovered another face of the same modern society whose other, more familiar, face we so admire."39 Such a somber assessment adds additional weight to the question of why the Holocaust — as well as the Soviet Gulag — plays such a marginal role in modern Confucianism's critical reflections on modernity.

It should be noticed that although Tang Junyi mentioned National Socialism and Stalinism in the context of totalitarianism, he did so only in passing, and without attempting to explore the implications of the Holocaust and the Gulag. Trying to provide a comprehensive explanation for such reservations would be tedious, perhaps even futile. Without a doubt, one would have to take into account the fact that by the 1950s and early 1960s, Chinese exiles' most immediate concern about totalitarianism was its Chinese manifestation, which they were quite literally facing from Hong Kong. It was therefore a particularly pressing topic, even more so in the general context of the Cold War period. To avoid an anachronistic default in intellectual history, one would moreover have to consider the international discussions and debates as well as the media coverage about the Holocaust up to the 197os (in Tang's case) and take into account the reception of these in the Chinese-speaking world. Even though there is a severe lack of research on this topic, it seems safe to say that 
Adorno and Arendt, for example - two of the most prominent thinkers of the immediate post-war period to reflect on the Holocaust as the other side of the modern society's coin-were largely unknown in Chinese circles in the 1950s and 1960 s.

Given these qualifications and constraints, simply brushing aside the topic with respect to Confucian critics seems prudent. However, the whole issue has a sting to it because, for one, modern Confucianism emphatically insists on its responsibility to address an international public, and not solely the Chinese audience. This, if nothing else, validates the concern of examining Confucian reflections on the Holocaust-or rather, the lack thereof. This concern would arguably not need such validation in the first place. Be that as it may, instead of asking why modern Confucianism continues to marginalize the Holocaust, one might rather be inclined to think about the upshot of overcoming such neglect. This is, in other words, a matter of pondering the consequences for modern Confucianism if it were "to treat the Holocaust as a rare, yet significant and reliable, test of the hidden possibilities of modern society" 40 and hence share "...the [disturbing] awareness that 'if it could happen on such a massive scale elsewhere, then it can happen anywhere; it is all within the range of human possibility...." 41

From such a perspective, serious doubts might be raised about modern Confucianism's optimistic assumption that modernity-as-modernization is, on the whole, a process leading to the betterment of human society. This assumption rests, after all, on the conviction that the dangerous excesses of modernization coupled with instrumental rationality may be swiftly contained by a collective effort based on commonly shared humanistic concerns and values. In this context, modern Confucianism depicts the threat of the human being's reification in societies undergoing rapid economic and technological transformation as pertaining to the authenticity of the individuals' way of life. But the lethal threat industrialized reification posed in death camps is met with silence. By neglecting this terminal point of "the hidden possibilities of modern society," modern Confucianism misjudges the real danger of reification. It also disregards the fact that the genocide on the scale of the Holocaust involved highly advanced, modern bureaucratic procedures, technological achievements, industrial organization and pseudo-scientific theories.

It is, moreover, doubtful whether modern Confucianism is prepared to reflect on the fact that as the Holocaust moved forward, its bureaucratic routinization and industrial mechanisms established assiduous functional

\footnotetext{
$40 \quad$ Ibid., p. 12.

41 Ibid., p. 11.
} 
patterns and structures on the basis of which perpetrators and sympathizers cast aside moral concerns. When applying a Confucian approach that essentially relies on a normative juxtaposition of instrumental and moral rationality, the Holocaust cannot be adequately described, let alone analyzed. The same holds true for attempts to grasp the mind-set of the bystanders: simply describing them as morally degenerate individuals or as a mass of people who were cut off from ethical relations and deprived of a humanistic education would be incorrect. The Holocaust resulted, in other words, not just from a temporary absence or weakness of moral rationality, humanistic culture and ethics vis-à-vis instrumental rationality, but "... was born and executed in our modern rational society, at the high stage of our civilization and at the peak of human cultural achievement ..." 42 When seen from this perspective, it is questionable whether the Confucian vision of modernity, with its highly optimistic expectation of a modernization guided by a renewed humanistic culture, may apprehend "... the most terrifying, and still most topical, aspect of the 'Holocaust experience': that in our modern society people who are neither morally corrupt nor prejudiced may also still partake with vigour and dedication in the destruction of targeted categories of human beings... This is by far the most important lesson of the Holocaust." 43

This "lesson" seems to thwart depictions of totalitarianism as an epiphenomenon of modernity that may be eliminated by a Confucian project integrating the renewal of humanistic culture and efforts of democratic nation-state building. The reflection on the Holocaust sobers optimistic outlooks on modernity. Two conclusions may be drawn here: first, the analytical and conceptual resources of modern Confucianism provide an inadequate basis for reflecting on the process of modernity as entailing the possibility of a Holocaust. Second, keeping the reflection about the Holocaust at bay is indeed a precondition for preserving the kind of historical optimism that characterizes the vision of a superior, Confucianized project of modernization. This belief in the superiority of a modernization informed by Confucianism thus

42 Ibid., p.x. With respect to instrumental rationality, Bauman cogently analyses: "This is not to suggest that the incidence of the Holocaust was determined by modern bureaucracy or the culture of instrumental rationality it epitomizes; much less still, that modern bureaucracy must result in Holocaust-style phenomena. I do suggest, however, that the rules of instrumental rationality are singularly incapable of preventing such phenomena; that there is nothing in those rules which disqualifies the Holocaust-style methods of 'social engineering' as improper...": Bauman, ibid., pp. 17-18. 
comes at a considerable price, and its claim to establish a renewed humanism of global dimensions remains dubious.

However, Hannah Arendt raises another concern about the Holocaust in her controversial book Eichmann in Jerusalem, Tang Junyi's moral philosophy may address:

What we have demanded in these trials ... is that human beings be capable of telling right from wrong even when all they have to guide them is their own judgment, which, moreover, happens to be completely at odds with what they must regard as the unanimous opinion of all those around them. (...) These few who were still able to tell right from wrong went really only by their own judgments, and they did so freely; there were no rules to be abided by, under which the particular cases with which they were confronted could be subsumed. They had to decide each instance as it arose, because no rules existed for the unprecedented. ${ }^{44}$

Arendt reflects here on a social situation in which all conventionally authorized moral wisdom, established ethical rules and religious authorities fail, without exception, to provide individuals with sound moral judgments. The problematic that arises in such a situation not only concerns the correctness of moral judgments as such, but also alternative sources for moral judgments that individuals might tap into in order to acquire (or preserve) the ability to tell right from wrong. This latter issue echoes in Tang's thought. His moral philosophy, as an integral element of the whole modern Confucian project, is a response to the deplorable state of China in the mid-2oth century: according to Tang, China was deprived of reliable moral standards by the 1950s-on the Mainland under communist control, as well as in Taiwan under the authoritarian regime of the GMD. Modern Confucianism was thus confronted with the issue of identifying reliable sources of correct moral judgment. However, Tang and other Confucian intellectuals did not address this issue by relating it to totalitarianism in as straightforward manner as Hannah Arendt did.

Still, Tang was evidently convinced that propagating Confucian moral values and virtues in societies threatened by totalitarianism - no matter how diligently this was done-would not suffice to secure correct moral judgments, let alone prevent totalitarian takeovers. Nor would it effectively reduce the spread of indifference and passiveness on the part of the bystanders once the shift to a regime of terror had begun. As a matter of fact, Tang remained skeptical with

44 Arendt, Hannah. Eichmann in Jerusalem: A Report on the Banality of Evil (New York: Viking Press, 1964), pp. 294-295, quoted from Bauman, Modernity and the Holocaust, p. 177. 
respect to the moral impact of Confucianism in modernizing societies, even if those societies were not immediately endangered by totalitarianism. In 1965, he expressed his skepticism as follows:

... the modern industrialized community is highly departmentalized in its structure by the division of labor. Here man must particularize in something, has his special profession, and consequently has his special social position in a corner of the complicated structure. Man's moral practice as demanded by the modern community is just to be loyal to his special profession and not feel ashamed of his special position. Here the Confucian idea of the whole man as a cultural and moral being seems inadequate to be the spiritual ground for the establishment of modern community and modern vocational morality. ${ }^{45}$

He consequently refrained from turning his moral thought into a search for allegedly superior moral values and virtues or ethical practices. His reflection on a Confucian concept of morality and ethics did not lend itself to practical concerns in such an immediate, yet insufficiently complex manner. Instead, his moral thought is best described as centering on the issue of the self-image of individuals. What is at stake here is the capacity of individuals to conceive of themselves as solitary moral authorities, namely as sages capable of moral intuition. Such a self-depiction can be considered as an intrinsic requirement for the individuals' ability to make autonomous moral judgments. With its core concept of liang zhi, Tang's Confucian civil theology unfolds a moral vision that describes the individual as having immediate access to an innate source of judgments about right and wrong. This entails a tendency to de-emphasize the role of society as the producer of morality.

But liang zhi does not belong to this moral vision exclusively: notions of liang zhi, after all, also proved attractive to Chiang Kai-shek and his followers, as well as to 2oth-century Japanese militarists. It seems that there is an inevitable ambiguity to the notion of liang zhi. Given the idea of an intuitive enlightenment that is quintessentially aloof, in its immediacy, from any symbolic prefiguration and representation, any attempt to attach such enlightenment firmly to certain normative choices amounts to a precarious undertaking. Faced with such a dilemma, Tang inscribed his moral intuitionism into an ethics that stressed the individual's social responsibility. The Confucian individual was not to withdraw into the irrationality of purely spiritual inwardness, but rather called upon to bear the tension between the requirements of social life 
and the continuous effort to realize the self-image of becoming the sole mediator of the "inner sage." Still, the individual is seen as not bound by conventionally sanctioned moral rules in realizing his or her capacity for moral intuition. Tang's modern Confucianism addresses, in other words, "the question of moral responsibility for resisting socialization" 46 — and hence a problem that belongs to the reflection on the Holocaust.

46 Bauman, Modernity and the Holocaust, p. 177. 